\title{
Vitamins C, E, and NADH on in Vitro Lymphocyte Proliferation and Redox Status among Obese Patients
}

\section{Asmaa Meraou1,2, Hafida Merzouk1, Amel Saidi', Amel Medjdoub1, Sid Ahmed Merzouk³, Slimane Belbraouet ${ }^{*}$}

${ }^{1}$ Laboratory of Physiology, Physiopathology and Biochemistry of Nutrition, Department of Biology, Faculty of Natural and Life Sciences, Earth and Universe, University Abou-Bekr Belkaïd of Tlemcen, Tlemcen, Algeria

${ }^{2}$ University Djilali liabes of Sidi Bel Abbes, Sidi Bel Abbes, Algeria

${ }^{3}$ Department of Technical Sciences, Faculty of Engineering, University Abou-Bekr Belkaïd of Tlemcen, Tlemcen, Algeria

${ }^{4}$ École de Nutrition, Université de Moncton, Moncton, Canada

Email: ^Slimane.belbraouet@umoncton.ca

How to cite this paper: Meraou, A., Merzouk, H., Saidi, A., Medjdoub, A., Merzouk, S.A. and Belbraouet, S. (2016) Vitamins $\mathrm{C}, \mathrm{E}$, and NADH on in Vitro Lymphocyte Proliferation and Redox Status among Obese Patients. Food and Nutrition Sciences, 7, 1082-1098. http://dx.doi.org/10.4236/fns.2016.712104

Received: June 6, 2016

Accepted: October 14, 2016

Published: October 17, 2016

Copyright (c) 2016 by authors and Scientific Research Publishing Inc. This work is licensed under the Creative Commons Attribution International License (CC BY 4.0).

http://creativecommons.org/licenses/by/4.0/ (c) (i) Open Access

\begin{abstract}
Background: The prevalence of overweight and obesity associated with oxidative stress and immune abnormalities is continuously increasing. Antioxidant supplementations might counteract potential damage caused by ROS to cellular tissues. Objective: To determine the role of vitamins on immune improvement during obesity, we investigated in vitro effects of vitamins $\mathrm{C}, \mathrm{E}$, and $\mathrm{NADH}$ on mitogen-stimulated proliferation, Th1- and Th2-type cytokine production, and oxidant/antioxidant status of lymphocytes isolated from obese patients. Methods: Peripheral blood lymphocytes were isolated using a density gradient of Histopaque. They were in vitro cultured and stimulated by Con $\mathrm{A}$ in the presence or absence of vitamins. Cell proliferation was determined by MTT assay and interleukin-2, interleukin- 4 and interferon- $\gamma$ (INF $\gamma$ ) secretions. Cell oxidant/antioxidant balance was studied by assaying glutathione (GSH), malondialdehyde (MDA), carbonyl protein levels, catalase activity and micronucli frequency. Results: Obesity is associated with enhanced oxidative stress response. Indeed, vitamin $\mathrm{C}, \mathrm{E}$ and $\mathrm{NADH}$ improved significantly lymphocyte proliferation and diminished cellular oxidative stress. Conclusion: Treatments of lymphocytes with vitamins had beneficial effects on lymphocyte proliferation, cytokines secretions and redox status, generating an anti-inflammatory profile and should be considered in therapeutic approaches for normalizing immune cell function in obesity.
\end{abstract}

\section{Keywords}

Obesity, Lymphocytes, Vitamins, Cytokines, Oxidant/Antioxidant Status 


\section{Introduction}

The prevalence of excess weight and obesity is continuously increasing, affecting millions of adults and children in developed and developing nations [1]. The excessive accumulation of body fat is linked with several health problems and metabolic disorders including insulin resistance, diabetes mellitus, dyslipidemia, and cardiovascular disorders [2]. Several studies have shown that obesity is associated with a chronic inflammatory state that may contribute to the development of many obesity-related co-morbidities and lipid metabolism and tissue function alterations [3]-[5]. Obesity is also recognized as a state of chronic oxidative stress related to inadequate antioxidant defences and increased free radical formation [6] [7].

Obesity has been eventually related to impaired immunity linked to metabolic changes in T lymphocyte and phagocyte functions leading to altered immune competence [5] [8]-[10]. The high leptin levels in obesity can increase T cell proliferation and cause dysregulation in lymphocyte subgroups [11]. Cytokines, important regulators of immune function, play a crucial role in lymphocyte activation, proliferation and differentiation. During obesity, the secretion of cytokines, especially IL-2 and IL-4, is altered, according to previous studies [12]. Obesity-associated insulin resistance is consistently associated with elevated levels of pro-inflammatory cytokines such as TNF $\alpha$, IL-6, and IL-1 $\beta$ [13] [14]. Obesity is also associated with the loss of anti-inflammatory regulatory T cells (Tregs), as well as the appearance of B cells, NK cells, NKT cells, eosinophils, neutrophils and mast cells [15]. It has been proved that increased susceptibility to infections and alteration of many immune functions are due to excessive nutrient intake [16]. Micronutrient deficiencies also induce adverse changes in immune function [17]. Vitamin deficiencies affect innate $\mathrm{T}$ cell-mediated immune response and adaptive antibody response [18]. Micronutrient deficiencies have been observed in obese patients, and they may influence several physiological functions with immune system impairment [19]. Several studies have thus focused on the effects of specific nutrient supplementation with respect to immune modulation [20] [21]. Immunomodulation may result in stimulation of lymphocyte proliferation, cytokine secretion, and/or homeostasis between T helper 1 (Th1) and Th2 lymphocytes [22].

Proliferation, activation and secretion of cytokine by $\mathrm{T}$ cells are regulated by intracellular Reactive Oxygen Species (ROS) which play a role in peripheral $\mathrm{T}$ cell homeostasis [23]. However, excessive ROS formation leading to oxidative stress and prolonged exposure to high ROS concentrations induces immune dysfunction, inhibits $\mathrm{T}$ cell proliferation and leads to apoptosis [24]. Evidence has been provided that biomarkers of oxidative damage are high in individuals with obesity, thus worsening immune dysregulation and the pro-inflammatory state [25]. Given that obesity is associated with oxidative stress and immune abnormalities, antioxidant supplementations might counteract potential damage to cellular tissue caused by ROS and modulate cell immunity, and should be considered in therapeutic approaches for normalizing immune cell function in obesity.

Vitamins $\mathrm{C}, \mathrm{E}$ and $\mathrm{NADH}$ can participate as antioxidants, modulate the immune 
system and protect it against free radicals. Vitamins $\mathrm{C}$ and $\mathrm{E}$ are two essential nutrients that can scavenge free radicals and constitute a strong line of defence in retarding ROS-induced cellular damage. Indeed, vitamin $\mathrm{C}$ has been shown to increase lymphocyte proliferation, to reduce oxidative damage in cultured human lymphocytes and to protect against cell destruction [26]-[28]. Many studies proved that vitamin E enhanced the immune system, T-cell maturation, lymphocyte proliferation and cytokine production [29] [30]. The energizing coenzyme NADH has various biological functions including energy metabolism, mitochondrial function, calcium homeostasis and gene expression, and has been used as an antioxidant agent protecting cells against damage induced by exogenous or endogenous oxidants [31]-[33]. Although previous data provides information about the important immune and antioxidant roles of vitamins, there is no direct information on their effect on the immune response in obesity.

Therefore, in this study, we investigated the in vitro effects of vitamins $\mathrm{C}, \mathrm{E}$ and $\mathrm{NADH}$ on mitogen-stimulated proliferation, Th1- and Th2-type cytokine production and oxidant/antioxidant status of lymphocytes isolated from obese patients. We then used a lymphocyte transformation assay based on mitogen stimulation of lymphocytes, which is accepted as a technique to evaluate lymphocyte function. Our initial work constitutes a first step to explore immunomodulation of these vitamins during obesity.

\section{Material and Methods}

\subsection{Subjects}

The study population consisted of 50 normal weight men (BMI $18-24 \mathrm{~kg} / \mathrm{m}^{2}$ ) and 32 obese men $\left(\mathrm{BMI} \geq 30 \mathrm{~kg} / \mathrm{m}^{2}\right)$, aged 20 - 40 years and recruited from the Department of endocrinology, University Hospital of Tlemcen (Algeria) between September 2013 and July 2014. All men were non-smokers and not taking any medication known to influence lipid metabolism and immune system. The selected subjects had no pathological history or chronic diseases. All obese men were routinely seen by an endocrinologist to ensure that are without diabetes mellitus, hypertension, renal or cardiovascular diseases. The participation to this study was voluntary and all subjects gave their written, informed consent. The study was approved by the Ethical Committee of the Tlemcen University Hospital and was performed according to the Declaration of Helsinki. Eligibility criteria for the men included in this study were: informed consent, age between 20 and 40 years, BMI 18 to $24 \mathrm{~kg} / \mathrm{m}^{2}$ or $\geq 30 \mathrm{~kg} / \mathrm{m}^{2}$, absence of history of chronic diseases, non-smoking and not taking any medication known to influence lipid metabolism and immune system or vitamin supplements.

Exclusion criteria for the selected subjects were the presence of chronic diseases and taking any medication known to influence lipid metabolism and immune system or vitamin supplements.

\subsection{Blood Simples}

Fasting blood samples were collected in a volume of $4 \mathrm{~mL}$ and drawn from the arm 
veins and were aseptically collected in two ethylene diamine tetra-acetic acid (EDTA) tubes, one for biochemical parameters and the second for immediate lymphocyte isolation.

\subsection{Biochemical Analyses}

Plasma glucose, triglycerides and total cholesterol were determined by enzymatic methods (Kits Spinreact, Ctra. Santa Coloma, Spain).

\subsection{Isolation and in Vitro Lymphocyte Proliferation Assay}

Peripheral blood lymphocytes were obtained from venous blood using differential centrifugation by Histopaque 1077 (Sigma Aldrich). The peripheral blood lymphocytes were collected at the interface of plasma and Histopaque and washed with the RPMI (1640) culture medium (Gibco, USA). Cell viability was tested by Trypan blue exclusion method. The cells were counted in Malassez hemocytometer and suspended in complete RPMI 1640 (supplemented with HEPES buffer, fetal calf serum, L-glutamine, 2-mercaptoethanol, penicillin and streptomycin) at $4 \times 10^{6}$ cells $/ \mathrm{mL}$ concentration. Cells were cultured in triplicate in microtiter plates with or without $\mathrm{T}$-cell specific mitogen Concanavalin (Con A) (Sigma Aldrich) and maintained at $37^{\circ} \mathrm{C}$ in a $5 \% \mathrm{CO}_{2}$ humidified atmosphere for $48 \mathrm{~h}$. Aiming to determine the effects of vitamins, lymphocytes were incubated with vitamin $\mathrm{C}, \mathrm{E}$, and $\mathrm{NADH}$. The vitamin concentrations used were $50 \mu \mathrm{M}$ for vitamin $\mathrm{C}, 50 \mu \mathrm{M}$ for vitamin $\mathrm{E}$, and $500 \mu \mathrm{M}$ for NADH. Vitamin concentrations used in our study were chosen according to previous studies which showed that these concentrations did not affect cell viability [28] [34] [35]. After incubation for $48 \mathrm{~h}$ and centrifugation at $1500 \mathrm{rpm}$ for 10 minutes, the cells were removed and the supernatants were collected for cytokine analysis. The cells were counted and assessed for viability which was over $80 \%$ for all cultures in our experiments. Lymphocyte proliferation was evaluated by the widely method used, the MTT [3-(4,5-dimethyl thiazol-2-yl)2,5-diphenyl tetrazolium bromide] (Sigma) assay as previously described [36]. The stimulation index (SI) was expressed as percentage of the control.

\subsection{Interleukin-2, -4 and INF $\gamma$ Assay}

Interleukins (IL-2, IL-4) and interferon- $\gamma$ (INF $\gamma$ ) levels in cell culture supernatants were measured by using commercially available ELISA kits (R \& D System, Oxford, UK) as per instructions supplied with. Results are expressed as $\mathrm{pg} / \mathrm{mL}$. The Th1/Th2 ratio was evaluated as the IFN $\gamma / \mathrm{IL}-4$ ratio.

\subsection{Lymphocyte Redox Parameters}

\subsubsection{Lymphocyte GSH Assay}

After cell lysis, intracellular reduced glutathione (GSH) contents were measured by using a Bioxytech GSH-400 kit (OXIS International, Inc., Portland, OR, USA).

\subsubsection{Lymphocyte Antioxidant Catalase Activity Assay}

Catalase activity was determined in lymphocytes using spectrophotometric analysis of 
the rate of hydrogen peroxide decomposition at $240 \mathrm{~nm}$ according to a previous method [37].

\subsubsection{Lymphocyte MDA Assay}

The widely marker used for lipid peroxidation, malondialdehyde (MDA) in cell cultures was measured spectrophotometrically using thiobarbituric acid according to a method described previously [38].

\subsubsection{Lymphocyte Carbonyl Protein Assay}

Protein carbonyls were evaluated as biomarkers of protein oxidation by 2,4-dinitrophenylhydrazine reaction as previously reported [39].

\subsection{Micronucleus (MN) Assay}

To detect DNA damage, the MN assay was used. The presence of MN was assayed after blocking cell cytokinesis by the actin inhibitor cytochalasin B (Sigma), following the method and the established criteria for MN evaluation as previously described [40] [41]. In general, the criteria for scoring $M N$ are: 1 . The cells should be binucleated. 2 . The two nuclei in a binucleated cell should have intact nuclear membranes and be situated within the same cytoplasmic boundary. 3. The diameter of the MN should be less than one-third of the main nucleus. 4. MN is round or oval in shape. 5. MN should be separated from or marginally overlap with main nucleus as long as there is clear identification of the nuclear boundary. 6 . MN should have similar staining as the main nucleus.

\subsection{Statistical Analysis}

Results were expressed as mean $\pm \mathrm{SD}$. The student's test was applied to observe the significant difference between obese and control subjects. The data were analyzed by one way ANOVA followed by LSD (least significant difference) test for assaying statistical differences between multiple incubations. $\mathrm{P}<0.05$ was noted for the majority of significant differences between obese and control men, and also between the different incubations. The statistical analyses were done using STATISTICA software package (Statsoft, Paris, France). $P<0.05$ was considered statistically significant.

\section{Results}

\subsection{Biochemical Parameters}

Significant differences were found in plasma glucose levels in the obese group compared to the control group (Table 1). Significant differences were also obtained in plasma cholesterol and triglyceride concentrations between obese and control subjects.

\subsection{In Vitro Effects of Vitamins on Lymphocyte Proliferation}

Con A mitogen-stimulated proliferative responses, expressed as stimulation indices, of lymphocytes incubated with vitamins are shown in Table 2 . In the presence of vitamin 
$\mathrm{C}$ and NADH, lymphocyte proliferation was not affected in controls. However, vitamin $\mathrm{E}$ induced a significant increase in $\mathrm{T}$ lymphocyte proliferation. In obese patients, vitamins $\mathrm{C}, \mathrm{E}$ and $\mathrm{NADH}$ stimulated T lymphocyte proliferation. Obese patients showed a slight decrease in Con A-stimulated lymphocyte proliferation rate compared to the control value, but the difference was not statistically significant. In the presence of vitamin $\mathrm{C}$ and $\mathrm{NADH}$, cell proliferation in the obese group was higher than the control group; the effect was more pronounced with vitamin C.

\subsection{In Vitro Interleukin-2, -4 and INF $\gamma$ Secretion}

After $48 \mathrm{~h}$ of culture, the secretion of cytokines IL-2, IFN $\gamma$ and IL-4by Tlymphocytes was tested to evaluate the balance between Th1 (IL-2 and IFN $\gamma$ ) and Th2 (IL-4) phenotypes (Table 3). The changes in IL-2secretion observed in the different cultures were parallel to those seen in the proliferative responses. No significant differences were found between IL-2 levels of Con A-stimulated lymphocytes from obese and control groups. Vitamin $\mathrm{C}$ and NADH supplementation had no effect while vitamin E enhanced IL-2 secretion by lymphocytes of control subjects. In obese patients, the three vitamins increased lymphocyte IL-2 secretion, which became higher in obese subjects than in the control group. IL-4 levels secreted from Con A-stimulated lymphocytes

Table 1. Characteristics of the population studied.

\begin{tabular}{lcc}
\hline & Control group $(\mathrm{n}=\mathbf{5 0})$ & Obese group $(\mathrm{n}=\mathbf{3 2})$ \\
\hline Age $($ years $)$ & $31.62 \pm 5.65$ & $32.37 \pm 4.82$ \\
BMI $\left(\mathrm{kg} / \mathrm{m}^{2}\right)$ & $23.00 \pm 1.76$ & $33.84 \pm 2.00^{\star *}$ \\
Glucose $(\mathrm{mmol} / \mathrm{L})$ & $4.88 \pm 0.22$ & $6.73 \pm 0.21^{\star}$ \\
Total cholesterol $(\mathrm{mmol} / \mathrm{L})$ & $4.68 \pm 0.35$ & $5.43 \pm 0.35^{*}$ \\
Triglycerides $(\mathrm{mmol} / \mathrm{L})$ & $1.22 \pm 0.13$ & $1.82 \pm 0.17^{*}$ \\
\hline
\end{tabular}

Values are means \pm SD. BMI: Body mass index $\left(\right.$ Weight $/$ Height $\left.^{2}\right)$. Statistical comparison between obese and control groups was performed by Student $\mathrm{t}$ test. ${ }^{*} \mathrm{P}<0.01$. ${ }^{*} \mathrm{P}<0.001$.

Table 2. In vitro proliferative response (stimulation index) of Con A stimulated lymphocytes from obese and control subjects.

\begin{tabular}{lcc}
\hline & Control group & Obese group \\
\hline Con A & $212.33 \pm 18.25^{\mathrm{b}}$ & $205.28 \pm 15.92^{\mathrm{c}}$ \\
Con A + Vitamin C & $227.48 \pm 14.09^{\mathrm{b}}$ & $346.74 \pm 23.18^{* * \mathrm{a}}$ \\
Con A +Vitamin E & $253.36 \pm 19.83^{\mathrm{a}}$ & $262.39 \pm 21.40^{\mathrm{b}}$ \\
Con A + NADH & $229.33 \pm 12.65^{\mathrm{b}}$ & $268.18 \pm 11.79^{\star \mathrm{b}}$ \\
P (ANOVA) & 0.030 & 0.005 \\
\hline
\end{tabular}

The values are means \pm SD of triplicate assays from 32 obese patients and 50 healthy controls. Multiple comparisons were performed using ANOVA followed by the least significant difference (LSD) test. Letters a, b, c indicate significant differences between different incubations $(\mathrm{P}<0.05)$. Obese versus control within the same incubation: ${ }^{*} \mathrm{P}<$ $0.01 ;{ }^{* *} \mathrm{P}<0.001$. 
Table 3. In vitro interleukin (IL-2, IL-4) and interferon gamma (INF- $\gamma$ ) production of Con A stimulated lymphocytes from obese and control subjects.

\begin{tabular}{|c|c|c|}
\hline & Control group & Obese group \\
\hline \multicolumn{3}{|l|}{$\mathrm{IL}-2(\mathrm{pg} / \mathrm{mL})$} \\
\hline Con A & $2248.43 \pm 45^{\mathrm{b}}$ & $2223.39 \pm 84^{c}$ \\
\hline Con $\mathrm{A}+$ Vitamin $\mathrm{C}$ & $2259.58 \pm 76^{b}$ & $3548.79 \pm 65^{\star \star a}$ \\
\hline Con $\mathrm{A}+$ Vitamin $\mathrm{E}$ & $2649.08 \pm 85^{\mathrm{a}}$ & $2663.83 \pm 96^{\mathrm{b}}$ \\
\hline $\mathrm{Con} \mathrm{A}+\mathrm{NADH}$ & $2252.65 \pm 68^{b}$ & $2773 \pm 44^{\star \mathrm{b}}$ \\
\hline P (ANOVA) & 0.020 & 0.004 \\
\hline \multicolumn{3}{|l|}{ IL-4 (pg/mL) } \\
\hline Con A & $58.29 \pm 4.59$ & $31.02 \pm 2.66^{\star c}$ \\
\hline Con $\mathrm{A}+$ Vitamin $\mathrm{C}$ & $60.52 \pm 3.31$ & $45.65 \pm 1.05^{\star b}$ \\
\hline Con $\mathrm{A}+$ Vitamin $\mathrm{E}$ & $62.87 \pm 2.22$ & $50.61 \pm 1.02^{\star a}$ \\
\hline $\mathrm{Con} \mathrm{A}+\mathrm{NADH}$ & $60.44 \pm 2.56$ & $48.26 \pm 1.04^{\star * a}$ \\
\hline P (ANOVA) & 0.241 & 0.006 \\
\hline \multicolumn{3}{|l|}{ INF- $\gamma(\mathrm{pg} / \mathrm{mL})$} \\
\hline Con A & $454 \pm 30.96^{\mathrm{b}}$ & $268.42 \pm 36^{* * c}$ \\
\hline Con $\mathrm{A}+$ Vitamin $\mathrm{C}$ & $471.57 \pm 35.17^{\mathrm{b}}$ & $393.42 \pm 39^{\star b}$ \\
\hline Con A + Vitamin E & $599 \pm 37.25^{\mathrm{a}}$ & $441,63 \pm 38^{\star a}$ \\
\hline $\mathrm{Con} \mathrm{A}+\mathrm{NADH}$ & $466.92 \pm 49.99^{\mathrm{b}}$ & $468.34 \pm 33.39^{\mathrm{a}}$ \\
\hline P (ANOVA) & 0.008 & 0.007 \\
\hline
\end{tabular}

The values are means \pm SD of triplicate assays from 32 obese patients and 50 healthy controls. Multiple comparisons were performed using ANOVA followed by the least significant difference (LSD) test. Letters a, b, c indicate significant differences between different incubations $(\mathrm{P}<0.05)$. Obese versus control within the same incubation: ${ }^{*} \mathrm{P}<$ $0.01 ;{ }^{* *} \mathrm{P}<0.001$.

were significantly decreased in obese compared to control subjects. Supplementation with vitamins had no effect on IL-4 secretion in the control group while causing a significant rise in the obese group (Table 3). IFN $\gamma$ levels were unaffected by vitamin $\mathrm{C}$ and $\mathrm{NADH}$ while increasing significantly in the presence of vitamin $\mathrm{E}$ in the control group. In the obese group, all vitamins tested induced a significant increase in IFN $\gamma$ secretion by lymphocytes. However, IFN $\gamma$ levels were significantly lower in obese lymphocytes compared to controls, except in the presence of NADH which induced a normalization of IFN $\gamma$ secretion (Table 3). In Con A-stimulated lymphocytes from obese patients, the Th1/Th2 ratio measured as the ratio of IFN $\gamma$ to IL- 4 was similar to that found in controls (Figure 1). This ratio was unaffected by the addition of vitamin $\mathrm{C}$ and $\mathrm{NADH}$ but was increased by vitamin $\mathrm{E}$ in the control group. Supplementation with vitamins $\mathrm{C}$ and $\mathrm{E}$ had no effect on Th1/Th2 ratio while NADH increased it in obese patients. Indeed, this ratio became lower in the presence of vitamin $\mathrm{E}$ and higher in the presence of $\mathrm{NADH}$ in the obese group compared to the control group. 


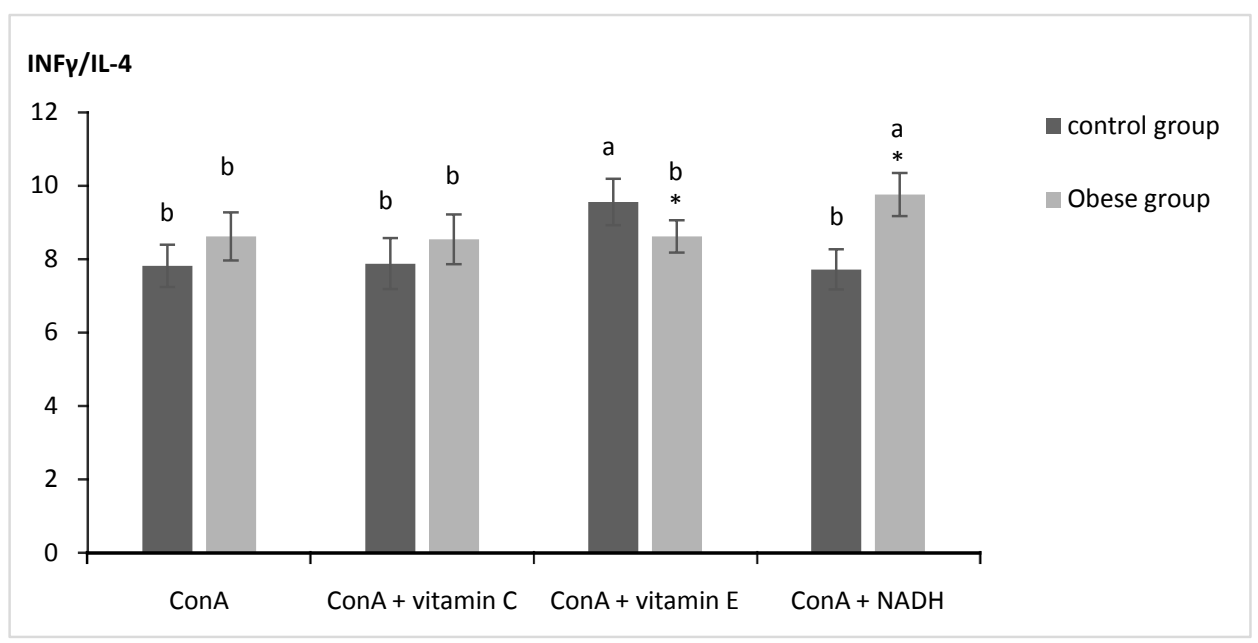

Figure 1. In vitro Th1/Th2 (INF $\gamma / \mathrm{IL}-4)$ ratio of con A stimulated lymphocytes from obese and control subjects. The values are means \pm SD of triplicate assays from 32 obese patients and 50 healthy controls. Multiple comparisons were performed using ANOVA followed by the least significant difference (LSD) test. Letters $a, b$ indicate significant differences between different incubations $(\mathrm{P}<0.05)$. Obese versus control within the same incubation: ${ }^{\star} \mathrm{P}<0.01$.

\subsection{Lymphocyte Redox Status}

\subsubsection{Lymphocyte GSH Content and Catalase Activity}

There were no significant differences in the GSH content of Con A-stimulated lymphocytes from the obese and control groups (Figure 2). Supplementation with vitamin $\mathrm{C}$ and NADH had no effect while vitamin $\mathrm{E}$ induced a significant rise in lymphocyte GSH levels in control subjects. In obese patients, vitamins $\mathrm{C}$ and $\mathrm{E}$ increased lymphocyte GSH content while NADH had no effect. Indeed, in the presence of vitamins $\mathrm{C}$ and E, GSH content of obese lymphocytes became higher than that of controls.

Lymphocyte catalase activity was reduced in obese subjects compared to the control group (Figure 2). Catalase activity was unaffected by addition of vitamins to control cultures. In the obese group, lymphocyte catalase activity was also unaffected by vitamin $\mathrm{C}$ and NADH. However, supplementation with vitamin $\mathrm{E}$ increased it and induced a normalization of this enzyme activity in obese patients.

\subsubsection{Lymphocyte MDA and Carbonyl Protein Content}

Lymphocyte MDA and carbonyl protein levels were significantly increased in obese subjects compared to the control group (Figure 3). These oxidative markers were unaffected by vitamin supplementation in control subjects. However, in obese patients, vitamins $\mathrm{C}, \mathrm{E}$ and $\mathrm{NADH}$ induced a significant fall in lymphocyte MDA and carbonyl protein amounts. In the presence of vitamins $\mathrm{C}$ and $\mathrm{E}$, MDA levels in obese lymphocytes became similar to control values. Carbonyl protein content of obese lymphocytes was only normalized by vitamin $\mathrm{E}$.

\subsection{Micronucleus Formation}

Table 4 illustrates the induction of micronuclei (MN) by micronutrients in stimulated 

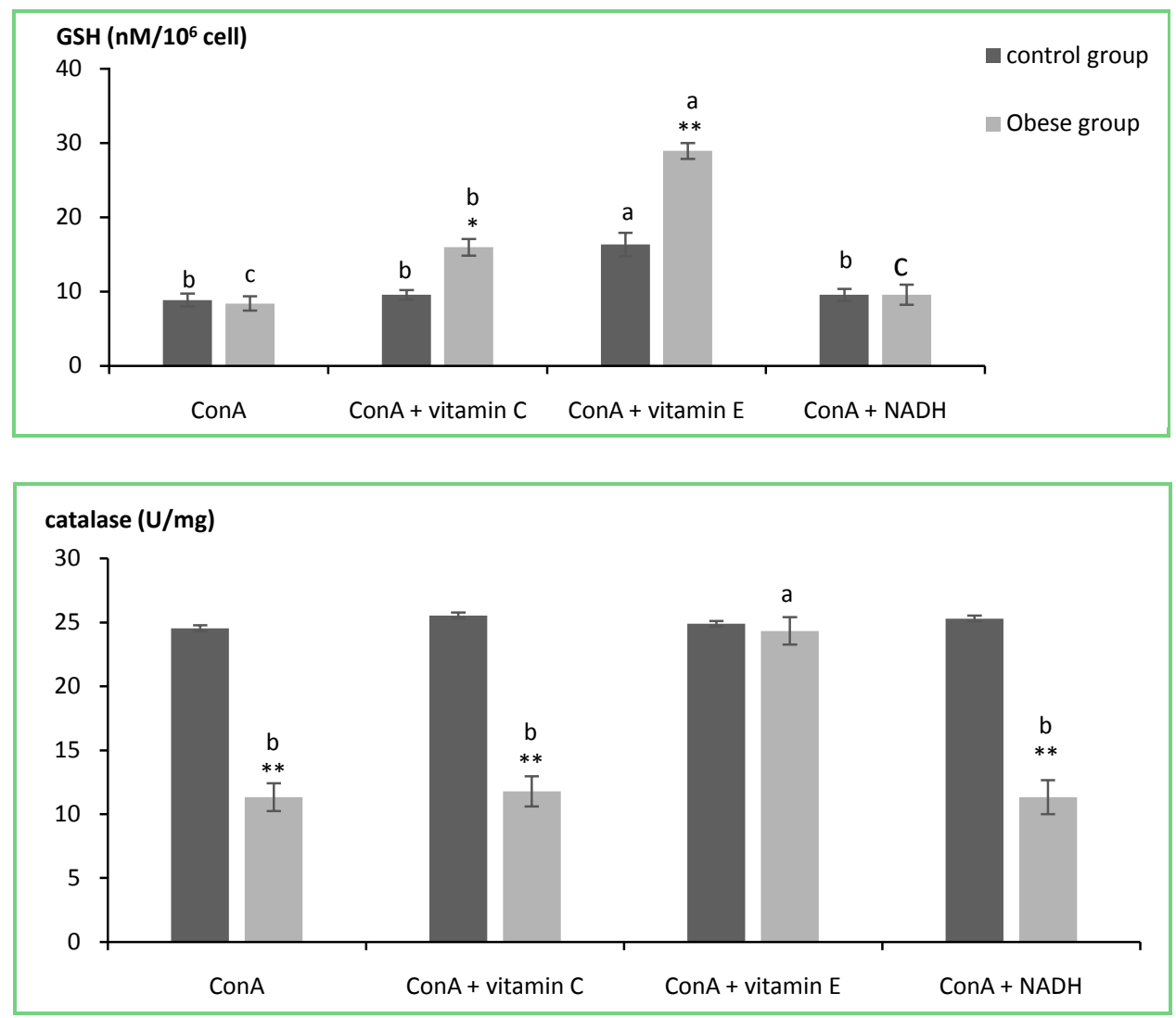

Figure 2. Intracellular antioxidant status of Con A stimulated lymphocytes from obese and control subjects. The values are means \pm SD of triplicate assays from 32 obese patients and 50 healthy controls. Multiple comparisons were performed using ANOVA followed by the least significant difference (LSD) test. Letters $a, b$ and $c$ indicate significant differences between different incubations $(\mathrm{P}<0.05)$. Obese versus control within the same incubation: ${ }^{\star} \mathrm{P}<0.01$.

T lymphocytes in obese subjects compared to the control group. The number of $\mathrm{MN}$ was significantly increased in Con A-stimulated $\mathrm{T}$ lymphocytes in the obese group compared to the control group. The addition of vitamins induced a significant decrease in $\mathrm{MN}$ number in the lymphocytes of obese patients, but had no effect on $\mathrm{MN}$ in control subjects. In the presence of vitamins $\mathrm{C}$ and $\mathrm{E}, \mathrm{MN}$ number in the obese group was normalized to control values.

\section{Discussion}

Obesity is associated with alterations in cellular immunity. Nutritional status has an important influence on the immune system and its function is very sensitive to nutritional changes [16]. Generally, most cases of obesity are thought to be caused by a combination of excessive food consumption and a sedentary life style [42]. The results of this study provided evidence that the presence of vitamins modulated lymphocyte proliferation, cytokine secretion and oxidant/antioxidant status in obesity.

In the present study, obese patients had high fasting glucose levels compared with controls, related to the IR state. These obese patients also had increased triglycerides 

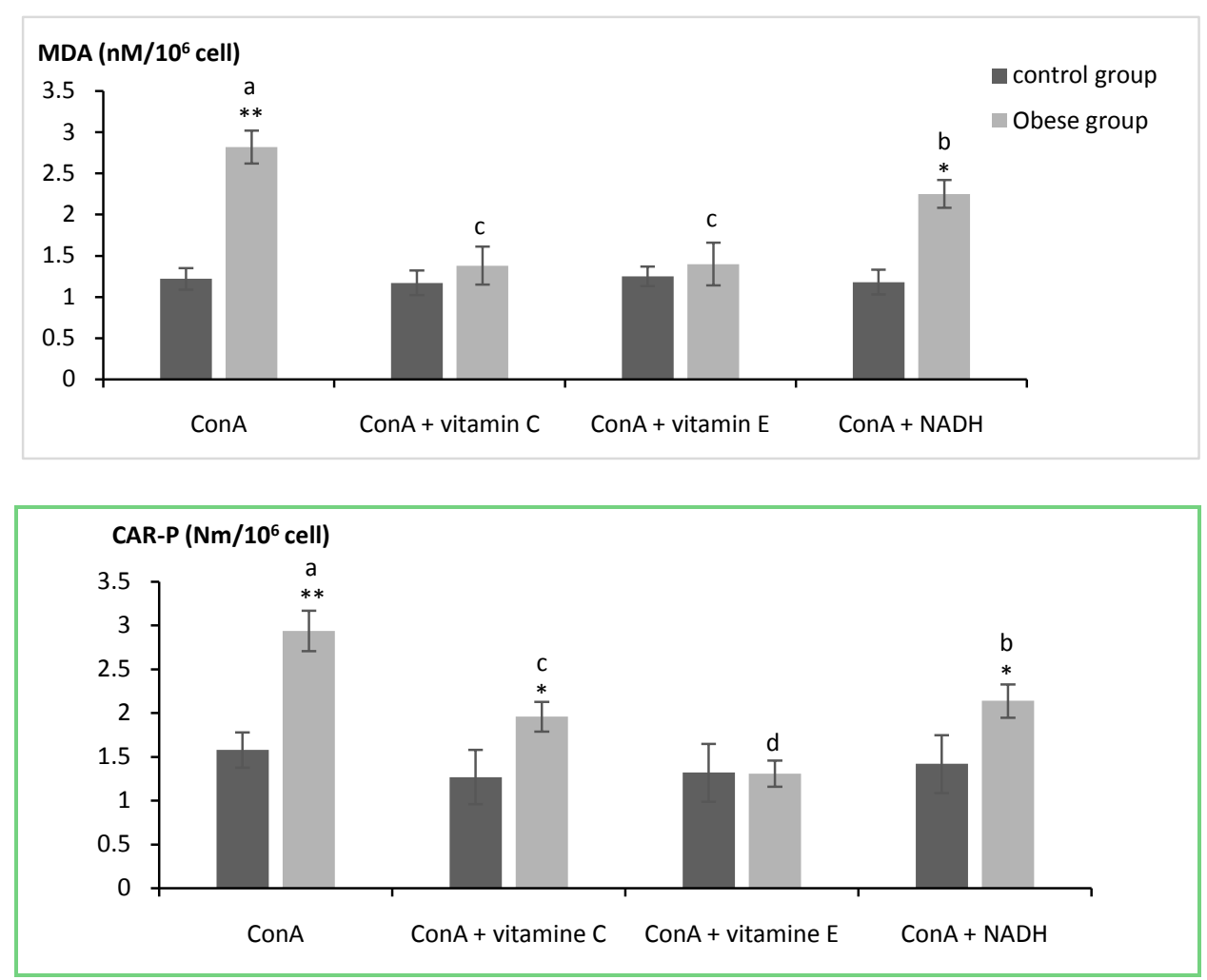

Figure 3. Intracellular oxidant status of Con A stimulated lymphocytes from obese and control subjects. The values are means \pm SD of triplicate assays from 32 obese patients and 50 healthy controls. Multiple comparisons were performed using ANOVA followed by the least significant difference (LSD) test. Letters $a, b$, and d indicate significant differences between different incubations $(\mathrm{P}<0.05)$. Obese versus control within the same incubation: ${ }^{\star} \mathrm{P}<0.01$.

Table 4. Induction of micronuclei by vitamins in Con A stimulated lymphocytes from obese and control subjects.

\begin{tabular}{ccc}
\hline & Control group & Obese group \\
\hline MN (\%) & & \\
Con A & $4.38 \pm 0.45$ & $7.56 \pm 0.55^{* \mathrm{a}}$ \\
Con A + Vitamin C & $4.84 \pm 0.35$ & $4.89 \pm 0.98^{\mathrm{c}}$ \\
Con A + Vitamin E & $4.46 \pm 0.42$ & $4.32 \pm 0.36^{\mathrm{c}}$ \\
Con A+ NADH & $4.65 \pm 0.48$ & $6.49 \pm 0.54^{* \mathrm{~b}}$ \\
P (ANOVA) & 0.247 & 0.006 \\
\hline
\end{tabular}

MN: micronuclei. The values are means \pm SD of triplicate assays from 32 obese patients and 50 healthy controls. Multiple comparisons were performed using ANOVA followed by the least significant difference (LSD) test. Letters a, b, $c$ indicate significant differences between different incubations $(P<0.05)$. Obese versus control within the same incubation: ${ }^{*} \mathrm{P}<0.01$.

and cholesterol concentrations compared to control groups, in agreement with a previous study [43] [44]. Adipose tissue IR and dysfunctional lipid storage in adipocytes are sentinel events in the progression toward metabolic dysregulation in obesity [43]. Previous studies in humans and animal models have shown altered lymphocyte num- 
bers, reduced lymphocyte responsiveness to mitogen stimulation and dysregulated cytokine expression in obesity [45] [46].

Since obese patients are at risk for vitamin deficiency [19], in this study we investigated the in vitro effects of vitamins on lymphocyte function and tried to determine whether these vitamins may contribute to immune improvement during obesity. In our study, Con A-stimulated lymphocyte proliferation in obese patients was similar to that found in controls. Since IL-2 is a potent T lymphocyte growth factor, normal IL-2 secretion by lymphocytes might be the reason for normalization of lymphocyte proliferation in obese patients. However, IL-4 and IFN $\gamma$ production by $\mathrm{T}$ lymphocytes after mitogen stimulation was reduced in obese patients compared with controls. Our findings were in agreement with a previous study that showed a decrease in cytokine secretion in obese patients [47] [48]. The INF $\gamma /$ IL-4 ratio was unchanged in obese patients, reflecting no change in the profile of Th1/Th2 lymphocytes. The current study demonstrated that obesity was associated with an enhanced oxidative stress response. In terms of antioxidants, there were no significant differences in the GSH content of Con Astimulated lymphocytes between the two groups. Our results agreed with the findings of others [49]. Lymphocyte catalase activity was reduced in obese patients compared to the control group, in agreement with previous studies [50] [51]. In addition, lymphocyte MDA and carbonyl protein levels were increased in obese patients compared to controls. A higher level of oxidant biomarkers strongly supports the presence of excessive oxidative stress in obesity as shown by several previous studies [7] [44]. Our results showed that vitamin supplementations have important in vitro modulatory effects on $\mathrm{T}$ cell function in obesity. The immunomodulatory effects of vitamins were evident in lymphocyte proliferation and cytokine secretion, with a significant reduction in intracellular oxidative stress shown in obese patients.

Vitamin $\mathrm{C}$ induced a significant increase in lymphocyte proliferation and incytokine (IL-2, IL-4 and INF $\gamma$ ) secretion in the obese group, while no changes were observed in the control group. In the presence of vitamin $\mathrm{C}$, the Th1/Th2 ratio was not affected in either the obese or control groups. Our findings are in agreement with previous studies showing an increase in the proliferative capacity of $\mathrm{T}$ lymphocytes treated with vitamin C [28] [52]. The results of this study provide evidence that vitamin $C$ reduced oxidative stress markers such as MDA and carbonyl protein levels and increased antioxidant GSH amounts in the obese group, while having no effect on those parameters in the control group. The low lymphocyte catalase activity in obese patients was unaffected by vitamin $\mathrm{C}$ treatment. It is well known that vitamin $\mathrm{C}$ acts as an efficient antioxidant against ROS generation. Our results are in line with other studies on different types of cells and diseases [26] [53]-[57].

In addition, our results showed that the addition of vitamin $\mathrm{E}$ enhanced lymphocyte proliferation in obese and control groups. This was accompanied by an increase in IL-2 and INF $\gamma$ secretion in both groups. However, vitamin $\mathrm{E}$ also induced an increase in IL-4 levels in the obese group with no change in the control group. Our results were in agreement with other studies showing the stimulatory effect of vitamin E on IL-2 and 
IFN $\gamma$ production [58] [59]. It is interesting to note that vitamin $\mathrm{E}$ induced an enhancement in the INF $\gamma / \mathrm{IL}-4$ ratio, generating a pro-inflammatory profile in controls. In the current study, the treatment of lymphocytes with vitamin E showed a powerful antioxidant effect, based on higher GSH levels in obese and control groups, and a significant increase in lymphocyte catalase activity in the obese group associated with low levels of MDA and carbonyl proteins while no changes were observed in controls. The effects of vitamin E seemed to be stronger in obese patients compared with controls. Our findings corroborated previous studies [56] [60]-[62].

Our results showed that NADH induced an increase in lymphocyte proliferation and in IL-2, INF $\gamma$ and IL-4 secretion in obese patients and had no effect in the control group. Our findings revealed that $\mathrm{NADH}$ possessed cytokine-modulating effects. A previous study showed that NADH could influence monocyte/macrophage function in peripheral blood by modulating IL-12 and TNF-alpha production [63]. NADH might be the key to protecting against free radicals and act as a direct antioxidant. The presence of NADH induced a decrease in lymphocyte MDA and carbonyl protein amounts. GSH and catalase activity activities were not affected by NADH. These findings were similar to those in previous studies [31] [32].

In general, our results revealed that vitamins $\mathrm{C}, \mathrm{E}$ and $\mathrm{NADH}$ induced an increase of IL-4 concentrations in obese patients. It should be pointed out that IL- 4 secreted by activated Th2 lymphocytes has a novel role in regulating lipid metabolism by inhibiting adipogenesis and promoting lipolysis [64]. MN frequency is a well-known marker of DNA damage. Our results revealed that vitamins $\mathrm{C}, \mathrm{E}$ and $\mathrm{NADH}$ induced a significant decrease in $\mathrm{MN}$ frequency in the obese group. Vitamins normalized $\mathrm{MN}$ formation in the obese group. Our findings confirmed that vitamins played an important role in protecting lymphocytes against oxidative and DNA damage, in agreement with previous findings [65] [66].

In conclusion, our results showed that treatment of lymphocytes with vitamins had beneficial effects on lymphocyte proliferation, cytokine secretion and redox status, generating an anti-inflammatory profile during obesity. Vitamin supplementation should be advised to improve immune response and oxidative stress in obese patients. Indeed, despite the beneficial effects of vitamin E, it generated a pro-inflammatory profile in non-obese subjects. Special attention must be paid to vitamin $\mathrm{E}$ intake.

\section{References}

[1] Papoutsakis, C., Priftis, K.N., Drakouli, M., Prifti, S., Konstantaki, E., Chondronikola, M., Antonogeorgos, G. and Matziou, V. (2013) Childhood Overweight/Obesity and Asthma: Is There a Link? A Systematic Review of Recent Epidemiologic Evidence. Journal of the Academy of Nutrition and Dietetic, 113, 77-105.

http://dx.doi.org/10.1016/j.jand.2012.08.025

[2] Dixon, J.B. (2010) The Effect of Obesity on Health Outcomes. Molecular and Cellular Endocrinology, 316, 104-108. http://dx.doi.org/10.1016/j.mce.2009.07.008

[3] Fain, J.N. (2006) Release of Interleukins and Other Inflammatory Cytokines by Human Adipose Tissue Is Enhanced in Obesity and Primarily Due to the Non Fat Cells. Vitamins 
and Hormones, 74, 443-477. http://dx.doi.org/10.1016/S0083-6729(06)74018-3

[4] Cancello, R. and Clement, K. (2006) Is Obesity an Inflammatory Illness? Role of low-Grade Inflammation and Macrophage Infiltration in Human White Adipose Tissue. BJOG: An International Journal of Obstetrics \& Gynaecology, 113, 1141-1147. http://dx.doi.org/10.1111/j.1471-0528.2006.01004.x

[5] Adeyemi, O.M., Vibhakar, S. and Evans, A.T. (2009) Obesity and Lymphocyte Subsets in Virologically Suppressed HIV-Infected Patients. Metabolism Clinical and Experimental, 58, 1285-1287. http://dx.doi.org/10.1016/j.metabol.2009.04.011

[6] Furukawa, S., Fujita, T., Shimabukuro, M., Iwaki, M., Yamada, Y., Nakajima, Y., Nakayama, O., Makishima, M., Matsuda, M. and Shimomura, I. (2004) Increased Oxidative Stress in Obesity and Its Impact on Metabolic Syndrome. The Journal of Clinical Investigation, 114, 1752-1761. http://dx.doi.org/10.1172/JCI21625

[7] Habib, S.A., Saad, E.A., Elsharkawy, A.A. and Attia, Z.R. (2015) Pro-Inflammatory Adipocytokines, Oxidative Stress, Insulin, $\mathrm{Zn}$ and $\mathrm{Cu}$ : Interrelations with Obesity in Egyptian Non-Diabetic Obese Children and Adolescents. Advances in Medical Sciences, 60, 179-185. http://dx.doi.org/10.1016/j.advms.2015.02.002

[8] Marti, A., Marcos, A. and Martinez, J.A. (2001) Obesity and Immune Function Relationships. Obesity Reviews, 2, 131-140. http://dx.doi.org/10.1046/j.1467-789x.2001.00025.x

[9] O’Rourke, R.W., Kay, T., Scholz, M.H., Diggs, B., Jobe, B.A., Lewinsohn, D.M. and Bakke, A.C. (2005) Alterations in T-Cell Subset Frequency in Peripheral Blood in Obesity. Obesity Surgery, 15, 1463-1468. http://dx.doi.org/10.1381/096089205774859308

[10] Nieman, D.C., Henson, D.A., Nehlsen-Cannarella, S.L., Ekkens, M., Utter, A.C., Butterworth, D.E. and Fagoaga, O.R. (1999) Influence of Obesity on Immune Function. Journal of the Academy of Nutrition and Dietetics, 99, 294-299. http://dx.doi.org/10.1016/S0002-8223(99)00077-2

[11] Matarese, G. (2000) Leptin and the Immune System: How Nutritional Status Influences the Immune Response. Eur Cytokine Netw, 11, 7-14.

[12] Han, S.N., Jeon, K.J., Kim, M.S., Kim, H.K. and Lee, A.J. (2011) Obesity with a Body Mass Index under 30 Does Not Significantly Impair the Immune Response in Young Adults. $\mathrm{Nu}$ trition Research, 31, 362-369. http://dx.doi.org/10.1016/j.nutres.2011.04.002

[13] Patel, P.S., Buras, E.D. and Balasubramanyam, A. (2013) The Role of the Immune System in Obesity and Insulin Resistance. Journal of Obesity, 2013, Article ID: 616193.

http://dx.doi.org/10.1155/2013/616193

[14] Feve, B. and Bastard, J.P. (2009) The Role of Interleukins in Insulin Resistance and Type 2 Diabetes Mellitus. Nature Reviews Endocrinology, 5, 305-311. http://dx.doi.org/10.1038/nrendo.2009.62

[15] Lumeng, C.N. and Saltiel, A.R. (2011) Inflammatory Links between Obesity and Metabolic Disease. The Journal of Clinical Investigation, 121, 2111-2117. http://dx.doi.org/10.1172/JCI57132

[16] Samartın, S. and Ranjit, K.C. (2001) Obesity, Overnutrition and the Immune System. Nutrition Research, 21, 243-262. http://dx.doi.org/10.1016/S0271-5317(00)00255-4

[17] Katona, P. and Katona-Apte, J. (2008) The Interaction between Nutrition and Infection. Clinical Infectious Diseases, 46, 1582-1588. http://dx.doi.org/10.1086/587658

[18] Wintergerst, E.S., Maggini, S. and Hornig, D.H. (2007) Contribution of Selected Vitamins and Trace Elements to Immune Function. Annals of Nutrition and Metabolism, 51, 301323. http://dx.doi.org/10.1159/000107673 
[19] Garcia, O.P., Long, K.Z. and Rosado, J.L. (2009) Impact of Micronutrient Deficiencies on Obesity. Nutrition Reviews, 67, 559-572. http://dx.doi.org/10.1111/j.1753-4887.2009.00228.x

[20] Shaik-Dasthagirisaheb, Y.B., Varvara, G., Murmura, G., Saggini, A., Caraffa, A., Antinolfi, P., Tete, S., Tripodi, D., Conti, F., Cianchetti, E., Toniato, E., Rosati, M., Speranza, L., Pantalone, A., Saggini, R., Tei, M., Speziali, A., Conti, P., Theoharides, T.C. and Pandolfi, F. (2013) Role of Vitamins D, E and C in Immunity and Inflammation. Journal of Biological Regulators and Homeostatic Agents, 27, 291-295.

[21] Farhangi, M.A., Keshavarz, S.A., Eshraghian, M., Ostadrahimi, A. and Saboor-Yaraghi, A.A. (2013) Vitamin A Supplementation and Serum Th1- and Th2-Associated Cytokine Response in Women. Journal of the American College of Nutrition, 32, 280-285. http://dx.doi.org/10.1080/07315724.2013.816616

[22] Mossman, T.T. and Sad, S. (1996) The Expanding Universe of T-Cell Subsets: Th1, Th2 and More. Immunology Today, 17, 138-146. http://dx.doi.org/10.1016/0167-5699(96)80606-2

[23] Cope, A.P. (2002) Studies of T-Cell Activation in Chronic Inflammation. Arthritis Research, 4, 197-211. http://dx.doi.org/10.1186/ar557

[24] Thoren, F.B., Betten, A., Romero, A.I. and Hellstrand, K. (2007) Cutting Edge: Antioxidative Properties of Myeloid Dendritic Cells: Protection of T Cells and NK Cells from Oxygen Radical-Induced Inactivation and Apoptosis. Journal of Immunology, 179, 21-25. http://dx.doi.org/10.4049/jimmunol.179.1.21

[25] Vincent, H.K. and Taylor, A.G. (2006) Biomarkers and Potential Mechanisms of ObesityInduced Oxidant Stress in Humans. International Journal of Obesity (London), 30, 400418. https://www.ncbi.nlm.nih.gov/pubmed/16302012 http://dx.doi.org/10.1038/sj.ijo.0803177

[26] Yasir, H.S., Tanveer, B. and Afzal, M. (2009) Protective Effect of Ascorbic Acid against Oxidative Damage Induced by Hydrogen Peroxide in Cultured Human Peripheral Blood Lymphocytes. Indian Journal of Clinical Biochemistry, 24, 294-300. http://dx.doi.org/10.1007/s12291-009-0055-5

[27] Ströhle, A. and Hahn, A. (2009) Vitamin C and Immune Function. Medizinische Monatsschrift fur Pharmazeuten, 32, 49-54.

[28] Molina, N., Morandi, A.C., Bolin, A.P. and Otton, R. (2014) Comparative Effect of Fucoxanthin and Vitamin $\mathrm{C}$ on Oxidative and Functional Parameters of Human Lymphocytes. International Immunopharmacology, 22, 41-50. http://dx.doi.org/10.1016/j.intimp.2014.06.026

[29] Fenech, M., Dreosti, I. and Aitken, C. (1997) Vitamin-E Supplements and Their Effect on Vitamin-E Status in Blood and Genetic Damage Rate in Peripheral Blood Lymphocytes. Carcinogenesis, 18, 359-364. http://dx.doi.org/10.1093/carcin/18.2.359

[30] Serafini, M. (2000) Dietary Vitamin E and T Cell-Mediated Function in the Elderly: Effectiveness and Mechanism of Action. International Journal of Developmental Neuroscience, 18, 401-410. http://dx.doi.org/10.1016/S0736-5748(00)00016-2

[31] Olek, R.A., Ziolkowski, W., Kaczor, J.J., Greci, L., Popinigis, J. and Antosiewicz, J. (2004) Antioxidant Activity of NADH and Its Analogue-An in Vitro Study. Journal of Biochemistry and Molecular Biology, 37, 416-421. http://dx.doi.org/10.5483/BMBRep.2004.37.4.416

[32] Cavallini, L., Valente, M. and Bindoli, A. (1983) NADH and NADPH Inhibit Lipid Peroxidation Promoted by Hydroperoxides in Rat Liver Microsomes. Biochimica Biophysics Acta, 152, 339-345. http://dx.doi.org/10.1016/0005-2760(83)90132-7

[33] Ying, W. (2008) NAD/NADH and NADP/NADPH in Cellular Functions and Cell Death: 
Regulation and Biological Consequences. Antioxidants \& Redox Signaling, 10, 179-206. http://dx.doi.org/10.1089/ars.2007.1672

[34] Hernández, J., Garibay-Escobar, A., Mendoza-Mendoza, A., Pinelli-Saavedra, A. and Valenzuela, O. (2008) Effect of Exogenous Vitamin E on Proliferation and Cytokine Production in Peripheral Blood Mononuclear Cells from Patients with Tuberculosis. British Journal of Nutrition, 99, 224-229. http://dx.doi.org/10.1017/S0007114507795302

[35] Liu, F.Q. and Zhang, J.R. (2003) X-Ray Induced L02 Cells Damage Rescued by New Anti-Oxidant NADH. World Journal of Gastroenterology, 9, 1781-1785. http://dx.doi.org/10.3748/wjg.v9.i8.1781

[36] Mossman, T. (1983) Rapid Colorimetric Assay for Cellular Growth and Survival: Application to Proliferation and Cytotoxicity Assays. Journal of Immunological Methods, 65, 5563. http://dx.doi.org/10.1016/0022-1759(83)90303-4

[37] Aebi, H. (1974) Catalase in Methods of Enzymatic Analysis. In: Bergmayer, H.U., Ed., Chemie, 2nd Edition, Vol. 2, FRG, Weinheim, 673-684.

[38] Draper, H. and Hadley, M. (1990) Malondialdehyde Determination as Index of Lipid Peroxidation. Methods in Enzymology, 186, 421-431. http://dx.doi.org/10.1016/0076-6879(90)86135-I

[39] Levine, R.L., Garland, D., Oliver, C.N., Amici, A., Climent, I., Lenz, A.G., Ahn, B.W., Shaltiel, S. and Stadtman, E.R. (1990) Determination of Carbonyl Content in Oxidatively Modified Proteins. Methods in Enzymology, 186, 464-478.

http://dx.doi.org/10.1016/0076-6879(90)86141-H

[40] Fenech, M., Chang, W.P., Kirsch-Volders, M., Holland, N., Bonassi, S. and Zeiger, E. (2003) Human Micron Nucleus project. Detailed Description of the Scoring Criteria for the Cytokines Is Block Micronucleus Assay Using Isolated Human Lymphocyte Cultures. Mutation Research, 534, 65-75. http://dx.doi.org/10.1016/S1383-5718(02)00249-8

[41] Medjdoub, A., Merzouk, S.A., Merzouk, H., Chiali, F.Z. and Narce, M. (2011) Effects of Mancozeb and Metribuzin on in Vitro Proliferative Responses and Oxidative Stress of $\mathrm{Hu}$ man and Rat Spleen Lymphocytes Stimulated by Mitogens. Pesticide Biochemistry and Physiology, 101, 27-33. http://dx.doi.org/10.1016/j.pestbp.2011.06.002

[42] Mansur, R.B., Brietzke, E. and McIntyre, R.S. (2015) Is There a "Metabolic-Mood Syndrome"? A Review of the Relationship between Obesity and Mood Disorders. Neuroscience and Biobehavioral Reviews, 52, 89-104. http://dx.doi.org/10.1016/j.neubiorev.2014.12.017

[43] Fenger, R.V., Gonzalez-Quintela, A., Linneberg, A., Husemoen, L.L., Thuesen, B.H., Aadahl, M., Vidal, C., Skaaby, T., Sainz, J.C. and Calvo, E. (2013) The Relationship of Serum Triglycerides, Serum HDL, and Obesity to the Risk of Wheezing in 85,555 Adults. Respiratory Medicine, 107, 816-824. http://dx.doi.org/10.1016/j.rmed.2013.02.001

[44] Karaouzene, N., Merzouk, H., Aribi, M., Merzouk, S.A., Berrouiguet, A.Y., Tessier, C. and Narce, M. (2010) Effects of the Association of Aging and Obesity on Lipids Lipoproteins and Oxidative Stress Biomarkers: A Comparison of Older with Young Men. Nutrition, $\mathrm{Me}$ tabolism \& Cardiovascular Diseases, 21, 792-945. http://dx.doi.org/10.1016/j.numecd.2010.02.007

[45] Bandaru, P., Rajkumar, H. and Nappanveettil, G. (2013) The Impact of Obesity on Immune Response to Infection and Vaccine: An Insight into Plausible Mechanisms. Endocrinology \& Metabolic Syndrome, 2, 113.

[46] Tanaka, S., Inoue, S. and Isoda, F. (1993) Impaired Immunity in Obesity: Suppressed but Reversible Lymphocyte Responsiveness. International Journal of Obesity and Related Metabolic Disorders, 17, 631-636. 
[47] Sánchez-Zauco, N., Del Rio-Navarro, B., Gallardo-Casas, C., Del Rio-Chivardi, J., Muriel-Vizcaino, R., Rivera-Pazos, C., Huerta-Yepez, S. and Cruz-López, M. (2014) High Expression of Toll-Likereceptors 2 and 9 and Th1/Th2 Cytokines Profile in Obese Asthmatic Children. Allergy and Asthma Proceedings, 35, 34-41.

http://dx.doi.org/10.2500/aap.2014.35.3749

[48] Mito, N., Hosoda, T., Kato, C. and Sato, K. (2000) Change of Cytokine Balance in Diet-Induced Obese Mice. Metabolism, 49, 1295-1300. http://dx.doi.org/10.1053/meta.2000.9523

[49] Shaeer, E.K., Soliman, S.A. and El-Ghareeb, A.A. (2014) Obesity and Follicular Fluid Oxidative Stress: Relationship to ICSI Outcome. Middle East Fertility Society Journal, 19, 139143. http://dx.doi.org/10.1016/j.mefs.2013.07.002

[50] Viroonudomphol, D., Pongpaew, P., Tungtrongchitr, R., Phonrat, B., Supawan, V., Vudhivai, N. and Schelp, F.P. (2000) Erythrocyte Antioxidant Enzymes and Blood Pressure in Relation to Overweight and Obese Thai in Bangkok. Southeast Asian Journal of Tropical Medicine and Public Health, 31, 325-334.

[51] Fernández-Sánchez, A., Madrigal-Santillán, E., Bautista, M., Esquivel-Soto, J., MoralesGonzález, A., Esquivel-Chirino, C., Durante-Montiel, I., Sánchez-Rivera, G., Valadez-Vega, C. and Morales-González, J.A. (2011) Inflammation, Oxidative Stress, and Obesity. International Journal of Molecular Sciences, 12, 3117-3132. http://dx.doi.org/10.3390/ijms12053117

[52] Chang, H.H., Chen, C.S. and Lin, J.Y. (2009) High Dose Vitamin C Supplementation Increases the Th1/Th2 Cytokine Secretion Ratio, but Decreases Eosinophilic Infiltration in Bronchoalveolar Lavage Fluid of Ovalbumin-Sensitized and Challenged Mice. Journal of Agricultural and Food Chemistry, 57, 10471-10476. http://dx.doi.org/10.1021/jf902403p

[53] Cadenas, S., Rojas, C., Pérez-Campo, R., López-Torres, M. and Barja, G. (1994) Effect of Dietary Vitamin $\mathrm{C}$ and Catalase Inhibition of Antioxidants and Molecular Markers of Oxidative Damage in Guinea Pigs. Free Radical Research, 21, 109-118. http://dx.doi.org/10.3109/10715769409056562

[54] Block, G., Jensen, C.D., Morrow, J.D., Holland, N., Norkus, E.P., Milne, G.L., Hudes M., Dalvi, T.B., Crawford, P.B., Fung, E.B., Schumacher, L. and Harmatz, P. (2008) The Effect of Vitamins C and E on Biomarkers of Oxidative Stress Depends on Baseline Level. Free Radical Biology \& Medicine, 45, 377-384. http://dx.doi.org/10.1016/j.freeradbiomed.2008.04.005

[55] Drehmer, E., Muñiz, P., Valls, V., Saez, G. and Cabo, J. (1997) Oxygen Metabolism in Isolated Rat Hepatocytes in Obesity Influence of Vitamin C. Nutricion Hospitalaria, 12, 250256.

[56] Alpsoy, L., Yildirim, A. and Agar, G. (2009) The Antioxidant Effects of Vitamin A, C, and E on Aflatoxin B1-Induced Oxidative Stress in Human Lymphocytes. Toxicology and Industrial Health, 25, 121-127. http://dx.doi.org/10.1177/0748233709103413

[57] Goyal, M.M., Gajjar, D.U. and Patel, D.B. (2009) Effect of Vitamin C and E Activity on Surgically Removed Cataractous Human Lens Epithelium Cells. Indian Journal of Clinical Biochemistry, 24, 375-380. http://dx.doi.org/10.1007/s12291-009-0068-0

[58] Han, S.N., Wu, D., Ha, W.K., Beharka, A., Smith, D.E., Bender, B.S. and Meydani, S.N. (2000) Vitamin E Supplementation Increases T Helper 1 Cytokine Production in Old Mice Infected with Influenza Virus. Immunology, 100, 487-493. http://dx.doi.org/10.1046/j.1365-2567.2000.00070.x

[59] Kaiser, M.G., Block, S.S., Ciraci, C., Fang, W., Sifri, M. and Lamont, S.J. (2012) Effects of Dietary Vitamin E Type and Level on Lipopolysaccharide-Induced Cytokine mRNA Expression in Broiler Chicks. Poultry Science, 91, 1893-1898. 
http://dx.doi.org/10.3382/ps.2011-02116

[60] Faria, R.R., Abílio, V.C., Grassl, C., Chinen, C.C., Negrão, L.T., de Castro, J.P., Fukushiro D.F., Rodrigues, M.S., Gomes, P.H., Registro, S., de Carvalho, R.C., D’Almeida, V., Silva, R.H., Ribeiro, R.A. and Frussa-Filho, R. (2005) Beneficial Effects of Vitamin C and Vitamin E on Reserpine-Induced Oral Dyskinesia in Rats: Critical Role of Striatal Catalase Activity. Neuropharmacology, 48, 993-1001. http://dx.doi.org/10.1016/j.neuropharm.2005.01.014

[61] Barros, D.O., Xavier, S.M., Barbosa, C.O., Silva, R.F., Freitas, R.L., Maia, F.D, Oliveira, A.A., Freitas, R.M. and Takahashi, R.N. (2007) Effects of the Vitamin E in Catalase Activities in Hippocampus after Status Epilepticus Induced by Pilocarpine in Wistar Rats. Neuroscience Letters, 416, 227-230. http://dx.doi.org/10.1016/j.neulet.2007.01.057

[62] Ademoglu, E., Erbil, Y., Tam, B., Barbaros, U., Ilhan, E., Olgac, V. and Mutlu-Turkoglu, U. (2004) Do Vitamin E and Selenium Have Beneficial Effects on Trinitrobenzenesulfonic Acid-Induced Experimental Colitis. Digestive Diseases and Sciences, 49, 102-108. http://dx.doi.org/10.1023/B:DDAS.0000011610.47179.0b

[63] Kretowski, A., Myśliwiec, J., Szelachowska, M., Kinalski, M. and Kinalska, I. (2000) Nicotinamide Inhibits Enhanced in Vitro Production of Interleukin-12 and Tumour Necrosis Factor-Alpha in Peripheral Whole Blood of People at High Risk of Developing Type 1 Diabetes and People with Newly Diagnosed Type 1 Diabetes. Diabetes Research and Clinical Practice, 47, 81-86. http://dx.doi.org/10.1016/S0168-8227(99)00122-9

[64] Tsao, C.H., Shiau, M.Y., Chuang, P.H., Chang, Y.H. and Hwang, J. (2014) Interleukin-4 Regulates Lipid Metabolism by Inhibiting Adipogenesis and Promoting Lipolysis. Journal of Lipid Research, 55, 385-397. http://dx.doi.org/10.1194/jlr.M041392

[65] Konopacka, M. (2004) Role of Vitamin C in Oxidative DNA Damage. Postępy Higieny $i$ Medycyny Doświadczalnej, 58, 343-348.

[66] Hartmann, A., Niess, A.M., Grünert-Fuchs, M., Poch, B. and Speit, G. (1995) Vitamin E Prevents Exercise-Induced DNA Damage. Mutation Research, 346, 195-202. http://dx.doi.org/10.1016/0165-7992(95)90035-7 for you:

Accepting pre-submission inquiries through Email, Facebook, LinkedIn, Twitter, etc. A wide selection of journals (inclusive of 9 subjects, more than 200 journals)

Providing 24-hour high-quality service

User-friendly online submission system

Fair and swift peer-review system

Efficient typesetting and proofreading procedure

Display of the result of downloads and visits, as well as the number of cited articles

Maximum dissemination of your research work

Submit your manuscript at: http://papersubmission.scirp.org/

Or contact fns@scirp.org 